Przegląd Badań Edukacyjnych Educational Studies Review

ISSN 1895-4308

nr 30 (1/2020), s. 269-291

METODY ZBIERANIA I ANALIZY DANYCH W BADANIACH EDUKACYJNYCH

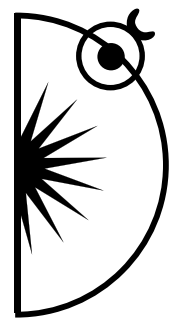

Gabriela Dobińska

ORCID: https://orcid.org/0000-0003-3629-5210

University of Lodz, Poland; e-mail: gabriela.dobinska@uni.lodz.pl

\title{
Theoretical and Methodological Aspects of Tacit Knowledge Research of Educators at Youth Educational Centres in Poland in the Context of Social Worlds Theory
}

http://dx.doi.org/10.12775/PBE.2020.015

\begin{abstract}
The aim of the article is to present theoretical and methodological reflections on research on the tacit knowledge and the social world of educators at młodzieżowe ośrodki wychowawcze [youth educational centres]. The introduction to the article contains a review of literature and an analysis of superior analytical categories in the context of social rehabilitation. Next, a methodological framework and preliminary assumptions regarding the test procedure are presented. The research project discussed in this paper is formed as an ethnography, the course of which is indicated by analytical procedures of the grounded theory methodology. The empirical material consists of a 12-month observation of everyday work of educators at youth educational centres and 17 interviews conducted with the educators at youth educational centres from Poland. The critical analysis of studies presents the challenges, potentials and values, as well as the difficulties resulting from limitations of the methodological assumptions. Three areas were analysed: negotiating the conditions for conducting research, defining the role of the researcher and the method of recruiting interviewees.
\end{abstract}

Key words: the theory of social worlds, tacit knowledge, qualitative research, social rehabilitation. 


\section{Introduction}

When analysing the available source literature and the results of studies based on social sciences one notices that the functioning of rehabilitation centres is studied mainly through the prism of the social climate (in the context of the total institution) and the functioning of pupils of rehabilitation institutions (Pytka, 1983; Zalewski, 2004; Sobczak, 2007; Skuza, 2012). Educators, perceived as an integrating force between the pupils and the outside world, are an overlooked aspect of research analysis (Konopczyński, 2016, pp. 5-10). Rehabilitation is defined as a conscious, intentional methodically and theoretically justified action, the purpose of which is to achieve relatively lasting effects on the functioning of pupils, through the creation of identity parameters (Konopczyński, 2015, p. 55). Therefore, educational reality consists of three elements: the subject of education (the pupils), the educational situation (educational objects) and the educator. The above links are correlated and co-dependent. The educator plays the role of an integrator, a filter of the non-institutionalised world, a distributor of inter-penetrating environments (the institutionalised and the non-institutionalised) and a gatekeeper, who, according to Kurt Lewin (1946, pp. 34-46), lets the pupils in through the door to the world of new values. On the basis of social sciences, there have been many studies on the educators of rehabilitation institutions conducted in the quantitative paradigm. Researchers emphasise the need to study the (actual) institutional reality with qualitative methods that allow penetration into the studied space and reconstruct the processes that create and sustain the social world of the institution (Zięba-Kołodziej, 2010, p. 354; Chomczyński, 2013, p. 232). The adoption of a quality strategy centred around the interpretive paradigm and the theoretical perspective of symbolic interactionism, with particular emphasis on the conciseness of social worlds, will enable reconstruction of the process of becoming an educator at mtodzieżowe ośrodki wychowawcze [youth educational centre] ${ }^{1}$. Considering the broad spectrum of issues concerning the social rehabilitation process, the work of an educator has a heterogeneous dimension, that is, a formal-administrative and humanist one, connected with supporting and accompanying changes in

${ }^{1}$ In the regulation of the Minister of Education of 28 August 2017, (chapter $3 \S 13$ ) "youth educational centres are for children and youth socially maladjusted requiring the use of a special organization of learning, working methods, upbringing, psychological and pedagogical assistance and social rehabilitation": http://prawo.sejm.gov.pl/isap.nsf/download.xsp/WDU20170001606/O/ D20171606.pdf. 
the identity parameters of socially maladjusted people (Jaworska, 2012, p. 92). An interesting approach is presented by Janusz Ropski (2010, p. 303), who indicated that educators spend most of their time with their pupils, becoming members of a symbolic institutional organisation. An educator may be a sort of "bridge" between an institution and society, in which pupils will function after leaving the rehabilitation institution. That is why the social world of educators is so interesting and unique.

A problematic aspect of the educator's work in a rehabilitation institution can be the specific character of overlapping plateaus of social contact between educator-educators, educator-pupil, educator-society (interaction occurring outside the social world).

\section{Social worlds theory}

The social world theory was generated under the influence of grounded theory methodology, and is related to the world of human actions and associated discourse. According to its author, Tamotsu Shibutani (1962, pp. 128-145), the social world can be regarded as a cultural area, which does not have clear territorial or formal boundaries, but where the limits of effective communication are specified. It constitutes a dynamic and interactive whole, which assumes permanent communication, unlimited participation and discourse. The fundamental analytical categories are boundaries, actions, technology, arenas, processes of legitimisation, segmentation, budding and intersecting of worlds (Strauss, 1993, pp. 78-85).

Shibutani (1962, pp. 564-566) distinguishes three types of social worlds. The first is based on strong community solidarity (e.g. social elite, underworld, ethnic minorities) often isolated from contact with the outside world. The next type is oriented on association structures (e.g. the world of medicine, organised work). The last type is loosely related universes with exceptional interests (e.g. the world of sport). The author emphasises that the world is a mosaic of social worlds, but each of them has its own communication channel within which the universe of discourse that strengthens the participant's identity and the distance of outsiders develops. A social world is created by people who perform specific actions, creating discourse devoted to them. The most important feature of a social world is primary activity, which constitutes a distinguishing criterion of a social world (Strauss, 1978, pp. 119-128). Anselm Strauss and Howard Becker (1963, pp. 67-85) defined social worlds as groups of people who have common commitments to perform specific actions, and who share resources 
which are fundamental to a common ideology and values, allowing them to achieve a common goal.

From the viewpoint of the suggested research topic, educators at rehabilitation centres (youth educational centres) are a group of people connected with each other by their activity, and involved in coherent and constant action. An inherent element of a social world is the construction of a universe of discourse - a social world is regarded as a space for communication, which imposes a common and coherent perspective on reality (Kacperczyk, 2012, pp. 275-277). Thus, a social world provides its participants with a cognitive perspective, which they can use to define situations. According to A. L. Strauss (1993, pp. 119-128), the phenomenon of communication and the multiplicity of its forms is fundamental to the preparation of types of group association. There is a multitude of theoretical concepts in the sociological literature concerning social worlds, especially those oriented around symbolic interactionism. The closest to the proposed research problem is the liquidity of the world of Strauss (2013, pp. 143-144), which assumes that the functioning of each group has a symbolic dimension and is organised around communication. The author himself indicates that "the idea of social worlds may refer centrally to the universes of discourse, that is why we should be careful not to look only at forms of communication, symbolization and universals of discourse, but also to examine tangible matters like activity, membership, places, technologies and typical organizations of specific social worlds " (Strauss, 1990, p. 235). This concept of social worlds makes it more tangible and palpable because, apart from the symbolic sphere, there is the real dimension of action.

The basis of each social world is common, basic action. Within one activity, sub-processes emerge (intersection of worlds, segmentation and legitimisation). Internal differentiation (segmentation) emerges as a result of distinct interests. Sub-worlds can be diverse due to numerous criteria - connecting features; spatial layout; used technology; ideology; skills; professional experience, etc. (Marzec, 2011, pp. 8-11). Legitimisation is connected with accentuating the uniqueness of basic action, as well as the unusual technology and procedures of its execution. An important feature which characterises social worlds is technology, which means resorting to a stock of specific technical means, which make it possible to perform actions (strategies, tools, procedures, tactics). The development of technology results in the professionalization of the basic action in a given social world. The next component of social worlds is boundaries, which are considered problematic. Their basic characteristic is fluidity (Kacperczyk, 2016, pp. 34-40). The more difficult it is to determine someone's belong- 
ing to a social world and his or her status, the more problematic the discussion on the criteria to define and locate oneself and other potential members of the world becomes (Słowińska, 2010, pp. 30-35). Arenas are a place of argument, they signify disagreement with the taken course of action. An arena is a place to discuss issues, which are problematic for the social world (negotiating, manipulating, imposing one's solution upon the representatives of the sub-worlds) (Strauss, 1978, p. 124). Each social world generates its own hierarchy of values, around which action is performed. Participants weave values into narratives, and thus pass them on to other participants for identity to become crystallised. The social worlds theory is close to the natural everyday experience of the world, in which fluidity, variation and disorder are natural attributes. The social worlds theory allows us to explain reality, but does not confine it to a rigid framework, thus leaving broad possibilities of application. The theory of social worlds allows the explanation of reality, but does not enclose it into a rigid framework, leaving wide application possibilities for creating a dense conceptual network. Accepting the discussed concept as a theoretical model in the study of educators at youth educational centres, the researcher has the opportunity to see invisible aspects of the experienced reality, the complexity of the phenomenon and the existing dependencies, connections and dynamics of the examined reality.

\section{Tacit knowledge and its study}

Tacit knowledge, the category which is of interest to the author, signifies hidden, secret knowledge (Zmyślony, 2012, pp. 65-82), transferred without using words and expressed through action. Implicit knowledge, a familiar term, indicates implication and involvement. Michael Polanyi (1958) used this concept for the first time to formulate the thesis that human knowledge consists of two types. Intersubjectively communicative knowledge, expressed by means of sentences or mathematical and natural formulas, as well as knowledge that a man cannot express in language, but can pass on to others and modify by undertaking various practical and theoretical actions. Polanyi's considerations gave rise to research on the relationship between explicit and tacit knowledge. At present, the tacit knowledge category operates on the basis of several dozen independent scientific disciplines, within which there is a multitude of interpretations and methods of learning tacit knowledge (Zmyślony, 2012, p. 45).

An important aspect of understanding the above terms is their non-verbalisation, and taking action in reality. Gilbert Ryle (2009, p. 34) emphasised declarative knowledge (knowing how) and processual knowledge (knowing that). 
The introduced types differ in the degree of introspective accessibility. Declarative knowledge can easily be verbalised because it is coded in the form of terms (acquired, conscious knowledge), whereas processual knowledge is hidden behind disposition to action, and its acquisition is a complicated process involving long-term repetitive actions and exercises. Processual knowledge reveals itself in action, while declarative knowledge is volitional in character. In source literature we usually distinguish two research approaches related to the category of tacit knowledge, that is, experimental and ecological (Nęcka at al., 2008, pp. 47-55). Taking into account the presented research project, the ecological approach proved to be of special significance. Authors attribute a procedural character, inaccessibility in introspection, direct connection with action, relativisation of subjects' individual aims and acquisition by means of personal experience to this paradigm. Expert knowledge is a special case of tacit knowledge, especially in relation to its acquisition, structuring, storage and application in praxeological space. Expert knowledge is characterised by personalisation, that is, it is relative to a given person (expert), and is procedural-processual in character. It is an expression of the ability to perceive patterns and relationships, as well as structures of similarity and differences hidden from lay people and "ordinary" experts, to introduce new problems and to seek creative solutions, to react with flexibility to new, unknown situations, to monitor and evaluate one's actions and knowledge and to aim at self-improvement (Chmielewska-Banaszak \& Magiera, 2004, pp. 751-763). Tacit knowledge inspired researchers to address networks of knowledge, which constantly encompass organisations.

In their research, Jean Lave and Etienne Wenger (1991; Bendkowski, 2014, pp. 6-21) focused on the relations between the learning process and the social environment. Based on the study results, it was established that contrary to the school environment, where learning occurs mostly in an abstract form, informal learning processes are directly connected with a given situation and thus constitute a social construct. Acquiring knowledge by "students" occurs through legitimising participation on the peripheries, consisting of learning from "masters" or more experienced colleagues. A central-peripheral structure is a result of adaptation to action, and the right to participate in the community is granted to those who gained legitimacy and who possess knowledge and competence necessary to take action. Ethnographic studies on copy machine maintenance men conducted by Julian Orr (1966, pp. 45-63) demonstrated that knowledge and action are closely tied. Moreover, Orr discovered that the greater part of the learning process transpires through interactions in informal social networks. Work is connected with narratives, telling stories and anecdotes, which carry 
(hidden) knowledge. "Stories from the battlefield" proved that work is connected with a specific situational context, which requires improvisation, intuition and ability

Nonaka and Takeuchi (2000) divided knowledge into explicit and implicit type. The first type is understood as available, formalised, containing facts and tangible data, easy to transfer in a codified way using computer programmes, textbooks and training. However the second type, hidden knowledge, is concerned with non-verbal, intuitive, highly individualised, acquired during longterm experience, which is difficult for identification and study. Close to the above considerations is the psychological concept regarding the model of acquiring expert knowledge consisting of three stages. According to the first of these, the novice (student) receives knowledge through personal relations with the (expert) master who organises it in the form of "scaffolding". In the next transitional stage, the scaffolding is successively filled with experiences, thanks to which the beginner begins to recognise patterns of action, while developing the ability to monitor and control his own cognitive activities. Skills become dominant at the last stage of self-regulation, when a qualified expert is equipped with the ability to independently expand and improve his professional knowledge. Expert knowledge pertains to an extremely narrow range of reality, acquired during long-term experience. The hidden nature of this knowledge lies in the fact that the expert sometimes does not realise that he has, interprets, communicates and is able to use it (Sternberg \& Hedlund, 2002; Collins, 2010).

Difficulties of a terminological and methodological nature rely on the liquidity and elusiveness of this concept, which makes it impossible to include it in a rigid definition framework. A research project of an ethnographic character enables observation as well as quasi-participation in the social world of educators at youth educational centres to identify (often) unverified tacit knowledge.

\section{Research study concept - methodological assumptions}

The presented concept of the research project is embedded in an interpretive paradigm, in which the world is perceived as a dynamic, unstable, changeable reality created by the actors of this world, impossible to predict and reconstruct. Reality is constructed as part of continuous symbolic interactions, where social roles and statuses are constructs subject for negotiations (Wilson, 1971; Hałas, 1987; Wyka, 1993; Konecki, 2000). The choice of a particular methodology and the adoption of a characteristic procedure should be a consequence of the analysis (Chomczyński, 2013, p. 98). I decided to adopt the interpretative paradigm 
because it finds his empirical grounding in qualitative research that captures social reality from the actor's perspective. Thus, it allows to understand the causes of social order in ongoing negotiation processes and negotiated interpretations of meanings (Szczepanik, 2015). Thomas Wilson emphasised that the issue of human attitude to the role is one of the main assumptions of the interpretative paradigm, especially in the aspect of the elements constituting the perception matrix operated by social actors giving meaning to the interactions in which they participate (Wilson, 1970; Chomczyński, 2015).

The theoretical basis of the discussed project is symbolic interactionism with particular emphasis on the theory of social worlds. Symbolic interactionism assumes that man affects objects in relation to the meanings they have. Thus, the individual does not react automatically to stimulants, but deliberately engages in activity by defining and interpreting his actions. In the view of representatives of intercommunication, man is an active subject which gives meaning to things and phenomena, intercommunicates, processes information, learns new social situations, interprets, makes analysis and, as a result, takes action (Denzin, 1978; Hałas, 1987; Mucha, 2003; Blumer, 2009). Adopting this orientation places the human in the centre of research interest, and not, instead, the social or institutional system. I am interested in reconstructing processes with their interactive context and capturing their complexity by discovering the ways in which educators of rehabilitation centres interpret their experiences and transfer these interpretations to activities. The main category of my research activities is the process of becoming an educator in a youth educational centre. "Becoming" is always a process related to a specific group; it can be understood in the context of socialisation or aspirations to achieve the status of a group member (Ślęzak, 2009). It is the group that sets the membership rules and inclusion conditions. The processuality occurs at various levels of interaction with the group; firstly, the actor aspires to be accepted to the given organisation, and then moves within various positions (Manning, 1971; Konecki, 2007; Marciniak, 2008). Therefore, exploration and description of the social world of rehabilitation centre educators (i.e. reconstruction of the creation process and maintaining the studied social world) combined with including the category of tacit knowledge in the research concept will allow to broaden the cognitive perspective. The theoretical orientation chosen requires the use of an appropriate methodology. Considering the adopted paradigm and theories, it should be noted that methods tend to lose their neutrality and acquire various meanings. Therefore, the adoption of a chosen methodology should be a consequence of the analysis of the research subject and research situation (Konecki, 2000; Chomczyński, 2013). 
The research project discussed in this paper is formed as an ethnography, the course of which is indicated by analytical procedures of grounded theory methodology (theoretical sampling and constant comparative method using the coding paradigm) (Corbin \& Strauss, 1990). I collected the data through field studies, using the techniques of observation and (unstructured) interviewing. Qualitative techniques enable us to understand the complexity of the social world of educators and to grasp its processual character. Furthermore, they allow us to "reach episodes of interaction at limited interference into the studied reality on the part of the researcher" (Konecki, 2000, p. 144). This enables us to learn the perspective of the actors, and to focus on the significance, which people ascribe to events in their lives, as well as to connect these meanings with the social world (Konecki, 2000, p. 125). Grounded theory methodology was developed by Glaser and Strauss, and is based on research on organisation and work processes (Glaser \& Strauss, 2009, p. 30). It consists of constructing a medium range theory based on meticulously collected empirical data. The theory is built through induction by way of precisely conducted field studies and collection of empirical data, and thus it adapts to the processual nature of the social world. In grounded theory methodology, it is assumed that no preliminary assumptions should be made at the beginning of the research procedure. Hypotheses, concepts and their properties are to emerge in the course of empirical studies and conducted analyses (Glaser \& Strauss, 2009, pp. 25-27). Grounded theory methodology provides an opportunity to become familiar with new and unexplored phenomena, which reveal themselves in the course of the research. An important process of the theory in question is the theoretical collection of samples and data in order to generate a theory. The researcher subsequently codes and analyses the collected data, and decides what further steps to take in order to develop a theory. Coding is a process of extracting categories and properties from collected material, through indicating the themes concerning conceptualisation. A significant element of grounded theory method is permanent, comparative data analysis (Charmaz, 2009 , p. 75). The end of the study is indicated by the moment of theoretical saturation, when successive studied cases do not contribute data, which develops the hypotheses and categories suggested earlier.

Grounded theory methodology can provide sufficient tools to analyse data collected during ethnographic studies (Ślęzak, 2016, p. 81). An ethnographic approach requires focusing on actions, and understanding "what" people do and "how" they do it. Thus, the most important questions, which are indicators for field researchers, are, what is happening and how it is happening, how involved are people, what differentiates and what connects the actions performed by 
a group (Kleinknecht, 2007, p. 23). Over the years, various directions of ethnographic research have emerged, all connected by fieldwork (in an environment which is specific to respondents), personalised studies, democratic relations based on a dialogue between researcher and respondents, synergy of several techniques of collecting data, researcher involvement, a holistic character and inductive reasoning (Angrosino, 2007, p. 11). The specific character of ethnographic research lies in its flexibility and lack of structured methodological instructions. Ethnographic research set within the framework of grounded theory methodology is based on a processual approach, which allows the researcher to build conceptual interpretations of the observed activities (Charmaz, 2009, pp. 34-35). A significant shift in the approach to ethnographic research came in the 1920s, when Chicago school researchers began to use anthropological achievements in methodology to study new problems (Angrosino, 2007). Cultivating the traditions of the precursors, "they came out from behind the desk to get their hands dirty in real research". Using the methodology of ethnography provides priority to empirical material coming from observation that is a natural human cognitive predisposition (Gabo, 2008).

Piotr Chomczyński (2013) exposed the nature of conducting research in institutions bearing traits of being total. The difficulty in reaching respondents and establishing relationships is due to the reluctance of informants to disclose their views, experiences and motives for action. This may be caused by fear of judgment, criticism, shame, revealing negative phenomena, addressing a socially controversial topic, distrust towards the researcher, and even perceiving the researcher as a representative of the institution's administration or law enforcement apparatus. Given the potential difficulties and the specifics of the research area, a reflective selection of research techniques should be made.

In order to collect empirical data I used the in-depth unstructured interview and open participant observation techniques. During the interviews, the respondents spoke about the way of perceiving the reality of the youth educational centre and about the way of defining themselves as educators (participants) of this world. They presented interpretive patterns of themselves as professionals. According to the assumptions of the methodology of the grounded theory, the purpose of the research is not the description of reality, but the reconstruction of processes taking place within the educators' social world. The free-form interview was comprised of two basic parts. Initiator's question: how did it happen that you became an educator of a youth educational centre, and supplementary questions, focusing on three levels of interaction: educator-other educators; educator-pupils; educator-society. 
Observation of everyday situations from the life of rehabilitation centres enable us to see the educators' unconscious or held back views and behaviours are motives for their actions. In addition, the educators during the interview with a completely foreign person (representative of the academic community) and aware of the conversation recording, ensured self-presentation and do not overlook the role of a professional. After the conversation, when the recorder is turned off, the narrators often asked how they performed and about the result of their speech. Conducting observations in a youth educational centre gives a chance for the natural behaviour of educators and forgetting about the presence of an additional (invisible) person. Thus, the collected empirical material under the proposed techniques complements each other.

Spontaneous statements by respondents are an extremely valuable source of data. Thus, being in a respondent group makes it possible to learn the characteristics of actions, vocabulary, terminology and categories, and to reconstruct the ideological framework within which the social world operates (Hammerslay \& Atkinson, 2000, p. 189). I conducted observations based on the peripheral member principle (Adler, 1994, pp. 236-246), which comprises observing and entering into close relations with respondents, without performing their primary (core) activities. Participation in the daily routine of a youth educational centre (focusing on unscripted situations as part of the class curriculum), may provide knowledge on the studied environment, and will also make it possible to see numerous interactions and communication (verbal and non-verbal), as well as emotions which accompany specific situations (Babbie, 2005, pp. 56-60). An important aspect of the research project is not limiting oneself merely to the observation of educators at the youth educational centre, but to try and attain a broader perspective of the educators' participation in scientific-method conferences, training sessions, courses and expert consultations. Data collected from observation is systematically noted and treated as equal to interviews. Consequently, following the specific character of grounded theory methodology, no observation was developed. Moreover, during observation the author intended to conduct informal (conversational) interviews (Konecki, 2005, p. 150 ), which in nature are informal conversations based on numerous tactics, such as building on questions (asked by a less experienced person - a trainee or an observer, who wants to obtain knowledge from an expert - an educator). Obtaining information by way of everyday informal conversations complemented the observations and in-depth unstructured interviews.

During the preparation of the research procedure, three connections were distinguished, which may be important in the exploration of the social world of 
educators of youth educational centres. In the educational space, those actions of educators, which are directed (workshops, planned talks, a series of thematic activities, an incidental project) are most frequently subject to evaluation. We can see a significant gap in considering the work of educators in everyday institutional undirected activities, which involve the pupils as well as other employees of the institutions. Morning activities, duties, meals, behaviour in baths, canteens and rooms and during trips are of interest, as well as conversations between educators and pupils, their tone of voice and body language, educators' ways of addressing pupils, habits, daily routines, common slang and humour. The above components contribute to the creation of the educator-pupil relationship. The next area is the educator-educator relationship, which enables one to emancipate and to experience failures and successes as well as the flow of expert advice and conflicts in preferred solutions and methods. This relationship is important for the process of becoming an educator and acquiring a professional identity.

This is where the values are created, the discourse of the universe, conflict spaces and sub-worlds. The final relation is that between the educator and the society (public), resulting from the collision and penetration of worlds in which educators function in a professional environment.

\section{Possibilities and limitations of the suggested research procedure}

An important aspect of the proposed project is the reconstruction of the process of becoming an educator in a youth educational centre and an analysis of the social world of educators in a youth educational centre (i.e. reconstruction of the processes that create and support the social world of institutions) in the context of tacit knowledge, taking into account the relations of educator-pupil; educator-educator; and educator-public (society). Within these interactions, processes of learning, interpretation and meaning take place, which results in defining oneself and other participants of the social world in accordance with the common perspective of perceiving reality (Charmaz, 2009, pp. 85-87).

In the attempt to reconstruct the process of becoming an educator - rehabilitation pedagogue - I made a central and basic goal. For maintaining terminological order, it should be mentioned that only a person who meets formal criteria resulting from legal acts (e.g. major studies completed, pedagogical preparation possessed) can become an educator of a youth educational centre. A review of the literature and research conducted demonstrates that, in addition to a formal legal condition, the educator should represent model social attitudes, 
have passions, competences and personality predispositions that allow for educational work with difficult youth. It turned out to be interesting how the educators identify and perceive themselves as educators, what meaning and attributes they assign to it, as well as how they perceive themselves in the perception of social discourse. Initially, I focused on the basic activity of the studied group, introduction of shared ideology, strategy of action, problems, presented values, methods and tools that educators use in the field of educational work, as well as considering the context of identity, involvement and professional socialisation, which in some measure define attributes of the social world (arenas, legitimations, sub-worlds, segmentations, boundaries) and tacit knowledge. Social worlds are not only shared ideology, values and specific communication, but also disputes, conflicts and negotiations that are essential for the continuity of the social world (Shibutani, 1962, p. 47). Such an understanding shows us the nature of the studied environment, bearing in mind its volatility. Despite the ordered structure and research concept, the first stage of research revealed several doubts and dilemmas of a methodological-organisational nature.

The presented research project is based on the unstructured interview and observation techniques, which became a problem in the first stage of the research. Establishing a relationship with the respondents and creating a comfortable atmosphere was by necessity time consuming, as well as undertaking formal action. The aim of the observation was to detect undirected, daily and spontaneous actions and situations in the relations between educators and pupils, educators and other educators, and participation of educators in the social world (outside) in the relationship between educators and society. While the third aspect is not problematic, entering an institution, crossing its threshold and being actively involved in the life inside a youth educational centre is much more difficult. In qualitative studies, the ability to establish an appropriate relationship with respondents is crucial (Hammerslay \& Atkinson, 2000, p. 35). For each technique (in this case interview and observation), the dynamics of interaction, duration of contact, assortment of roles, and the situation in which the respondent and researcher find themselves differ significantly (Ślęzak, 2016, pp. 225-235). Relations in the field should be democratic and be founded on dialogue, especially if the researcher participates (in part) in the life of the respondents (Patton, 1997, pp. 161-172). It was only through the goodwill of other, who vouched for me as trustworthy, that I was able to enter a rehabilitation institution. It was the beginning of negotiations regarding the formal conditions of undertaking field studies. Agnieszka Golczyńska-Grondas (2019) writes about the difficulties in conducting research involving people at risk of 
exclusion, excluded or associated with a marginalised environment, mentioning gatekeepers, who indirectly enable the realisation of research. Getting a "pass" and physical entry into the facility alone did not guarantee trust from employees who declared fatigue with continuous visits, student internships as well as controls and evaluations. The first stage of observation was extremely difficult for me and the respondents who tried to define my presence in their professional life. The most questionable for the respondents was to let me through the doorstep of the educators' room - the most sensitive and important place in the youth educational centre. The current ban for pupils on entry into this room has made it a command centre for educators. This is where consultations, exchange of information between educators, supervisions, and telephone conversations with other institutions, as well as daily, friendly conversations between educators, jokes and quarrels take place. Allowing me into the educators' room was, in some sense, an initiation and an "entrance" to the social world of educators.

The process of gaining trust goes on, taking the form of spontaneous-strategic actions, because the situation sometimes requires exceptional vigilance. Authors of source literature direct our attention to the category of "working to gain trust", which is especially important from the first moments of the research. Its essence are actions aimed at establishing a researcher-respondent relationship, which will be mutually satisfying, without entailing a sense of threat or danger (Hochschidl, 2012, pp. 46-50). The ethical controversy is raised by the neutrality of the researcher who, by participating in a given situation, grows into the situational context by establishing relations with the environment. The researcher becomes a creator of social activities, in which he is a participant, and a subject of social actors' activity who address content and actions to him (Chomczyński, 2006).

Further difficulties connected with observation, as noticed by the author, are "becoming accustomed" to data, and the systematising of the collected material. Grounded theory methodology implies that the researcher should not bring into the research process an equivalent with convictions, assumptions or preliminary hypotheses. However, conducting reliable observations, undistorted by the need to learn and experience novelty, may generate difficulties. In the course of a study, the researcher becomes used to and adapts to the conditions of the studied reality. This may interfere with his or her vigilance and sensitivity to detect relevant data. On the other hand, the status of a researcher (non-employee) prevents natural and free observation, especially given such restrictions as the duration of each observation and the impossibility of entering the life of the institution as a legitimate employee (Ślęzak, 2016). Meetings 
in the research team proved to be a way to organise empirical material and systematise knowledge and reflection. Group consultations (supervisions) and discussions with other researchers (representatives of social sciences) enabled me to systematically organise data and resolve dilemmas regarding subsequent stages of the research project.

Another problem area is the way in which interviewees are recruited, described in source literature by the term 'snowball effect' where a respondent indicates the next person who can participate in the study (Babbie, 2005, p. 313). The suggested strategy came to be appropriate; however, in the author's view, it involves the risk of uniformity, lack of differentiation in the respondent group, and difficulties with recruiting further informants. After conducting the first interviews it was noticed that the only criterion of sample selection (being an educator at a youth educational centre) may not be enough. On the other hand, given the educators' limited involvement in the study, and their reluctance to engage in conversation, there is a risk that introducing new differentiating criteria of sample selection (sex, age, professional experience, earlier work experience, etc.) could hinder the research process. After conducting 17 interviews, despite apprehension, it turned out that the obtained empirical material is diverse and opens many possibilities for analysis. Among the narrators (i.e. 5 men and 12 women) there was a possibility to specify people with various degrees of career advancement, seniority and previous professional experience. The diversity of cases allows the undertaking of more diverse analysis.

In my research, I have repeatedly experienced ethical dilemmas related to the observed reality and the information obtained from narrators. The emergence of sensitive, controversial issues, which aroused strong emotions or my disagreement as a rehabilitation pedagogue, verified me as a researcher. Konecki (2000) wrote about the experienced difficulties (emotional load and commitment), noting that the participation of the researcher-observer in the examined reality activates "interpersonal empathy", thanks to which the researcher reaches the meanings given by the participants of the examined reality. Through this, the researcher can incorporate his emotions into the analysis and interpretation of the phenomena studied. However, by a clear involvement while constructing conclusions about the reality examined, there is a danger that the researcher may fall into the trap of subjectivity, perception of phenomena only from his perspective, not the perspective of the observed subjects (Chomczyński, 2014). Szczepanik (2020) writes about difficulties in conducting qualitative research, paying attention to the role of the researcher marked by ambivalence. On the one hand, the researcher should show empathy and openness, on the other hand, 
he should remember about his role as a scientist and the need to maintain distance in relation to the respondent. The difficult experiences of the narrators become the researcher's personal experience. In addition, Lofland, Snow, Anderson and Lofland (2009) point out that a researcher who falls into the environment of socially excluded people is exposed to an extremely high emotional load. Consequences of involvement may be the researcher's guilt resulting from the privileged social status of the examined person, the feeling of stress, anxiety or a feeling of "double loyalty".

In addition to dilemmas, feelings of discomfort and difficult emotions arising from the relationship with the respondent, I experienced a feeling of satisfaction from the accumulated empirical material. "This is a specific feeling of relief and satisfaction from a "successful" interview, from the fact that one was "lucky" to find a person who not only has difficult experience, but also" talks "about them well and reconstructs threads smoothly. It is a state caused by the sudden realization of the lack of a natural "reflex" of compassion and sadness, because the "interest" of the researcher came to the fore, which overshadows difficult emotions and dominates the joy of acquiring an interesting case and a successful narrator" (Szczepanik, 2020, p. 203). Efekt lisich raczek [The fox hands effect $]^{2}$ brings very strong emotions. On the one hand, the joy of acquired material, on the other hand, sadness and remorse resulting from the researcher's reflection on his reaction. "The fox hands effect" is probably amplified when the researcher has difficulty in reaching the subjects, the research area is unavailable, when the researcher has experienced many "unsuccessful" interviews or his research oscillates around difficult problems (Szczepanik, 2020).

Finally, there occurred dilemmas connected with defining the researcher's role in the project. Despite disclosure and the awareness of the author's role as researcher among respondents, the dynamics of interaction deforms the image of the researcher, reducing it to completely different roles, which are expected

${ }^{2}$ Efekt lisich raczek [The fox hands effect] arose as a result of discussions during research team meetings during the scientific project "Family in the social support system and assistance to people with alcohol problems. Biographical research with parents of adult children addicted to alcohol" implemented as a task "Supporting scientific research in the area of problems arising from alcohol use", financed by the National Health Program for 2016-2020. The use of this metaphor referring to the "fox slyness" reduced tension and made it possible to distance oneself from the moral and ethical difficulties experienced by the team. The team was composed of: Renata Szczepanik, Mgdalena Staniaszek, Angelika Cieślikowska-Ryczko, Gabriela Dobińska, Agnieszka Jaros, Diana Müller-Siekierska, Karolina Walczak-Człapińska, Justyna Ratkowska-Pasikowska, Katarzyna Okólska, Paweł Leśniewski (Team of Special Education at the Faculty of Educational Sciences of the University of Lodz) (Szczepanik, 2020). 
at a specific moment by the respondents. This refers mostly to the ambiguity of the role of researcher-official; controller, researcher-omniscient professional, researcher-theoretician, researcher-(counter-)ally, and researcher-assistant (Ślęzak, 2016). Such situations occurred primarily during interviews, when respondents expected the researcher to provide solutions, advice and knowledge, and described their professional situations through the prism of statistical data or achievements and successes as well as accompanying emotions. In addition, narrators frequently resorted to digressions and telling anecdotes, often not related to the main topic of the interview. However, at the material analysis stage, it turned out to be extremely valuable information which generates new analytical categories.

\section{Conclusion}

As I demonstrated, establishing relationships with respondents, precise planning (arranging) of research activities and constant evaluation of one's decisions and actions are of great importance for the research process. Despite emerging doubts and considerations regarding further stages of the research, the empirical material collected so far is extremely valuable. The potential of the collected data (i.e. 17 interviews with educators at youth educational centres and annual observation of the professional reality of educators) is visible in the distinguishing of analytical categories of the social world of educators at youth educational centres as well as processes conducive to the "operation" of hidden knowledge. The social world of educators at youth educational centres is peculiar, which means the researcher should display goodwill and flexibility. However, he or she should also retain and preserve his or her role as researcher in order to avoid crossing boundaries and disrupting the research procedure.

When conducting qualitative studies researchers face numerous challenges, as well as ethical and methodological dilemmas. One of the fundamental challenges is establishing contact with respondents and creating comfortable conditions which enable the narrators to become more open. When I go through dilemmas I discover that the relationship between myself (the researcher) and the respondent is fluid and undergoes changes. In the course of the study, as a result of intense interactions, the mutual perception of partners evolves. Initially mistrust and dislike may be the primary categories through which both sides (i.e. researcher and respondent) perceive and define one another (Ślęzak, 2018). The issue connected with establishing relations, trust and emotions experienced by the researcher and the respondents are often the subject of con- 
sideration for social scientists (Niedbalski, 2016; Ślęzak, 2016; Szczepanik \& Śliwerski, 2017; Golczyńska-Grondas, 2019). In the project which I carried out building trust was a very significant element of the entire research procedure. The reason for this was the idiosyncratic character of the studied environment - educators at youth educational centres, who initially declared their reluctance to participate due to constant supervisions and inspections, and because they defined themselves through the lens of criticism of social rehabilitation institutions in Poland. Both the respondents and I implemented various role models and strategies of interaction with respect to our relations. The methodological and ethical dilemmas which I presented and discussed had significance for successive stages of the research and for the development of coping strategies with respect to certain difficulties. Awareness of these elements and of the idiosyncrasies of the studied professional group increases the researcher's sensitivity, thus improving their methodology of work. Moreover, reflection on experienced difficulties teaches us to react, to follow the respondents, to focus on "the here and the now" and to discard "professional rigidity". It is more often the case that researchers consider ethics in social studies (Chomczyński, 2006; Ślęzak, 2016; 2018; Golczyńska-Grondas, 2019). Perhaps systematic supervisions which could become a space for discussion on the project and on the role of the researcher, as well as methodological training, would be an effective solution (Grondas, 2019; Carrol, 2007).

\section{References}

Adler, P. A., Adler, P. (1994). Observational Techniques. In: K. Norman, Y. Denzin, \& S. Lincoln (Eds.), Handbook of Qualitative Research (pp. 377-392). Thousand Oaks: Sage.

Angrosino, M. (2007). Doing Ethnographic and Observational Research. London, Los Angeles, New Dehli, Singapore and Washington: SAGE.

Babbie, E. (2005). The Basic of Social Research. Boston: Cengage Learning Company.

Becker, H.S. (1963). Outsiders; Studies in the Sociology of Deviance. New York: The Free Press of Glencoe.

Bendkowski, J. (2014). Wspólnota działań w perspektywie badań organizacyjnych [CoP in the Organization Studies Literature]. Zeszyty Naukowe Politechniki Ślaskiej, 76, 6-21.

Blumer, H. (2009). Symbolic Interactionism: Perspective and Method. California: University of California Press.

Carrol, M. (2007). One More Time: What is Supervision. Psychotherapy in Australia, 13/3, 34-40. 
Charmaz, K. (2009). Teoria ugruntowana. Praktyczny przewodnik po analizie jakościowej [Constructing Grounded Theory]. Warszawa: Państwowe Wydawnictwo Naukowe.

Chmielewska-Banaszak, D., \& Magiera, E. (2004). Wiedza milcząca. Jawne versus utajone: nowe spojrzenie na poznawcze i społeczne funkcjonowanie człowieka [Tacit Knowledge. Explicit versus Latent: A New Look at Human Cognitive and Social Functioning]. Zagadnienia naukoznawstwa, 4, 751-763.

Chomczyński, P. (2006). Wybrane problemy etyczne w badaniach: obserwacja uczestnicząca ukryta [Selected Ethical Problems in Research: Hidden Participant Observation]. Przegląd Socjologii Jakościowej, 2/1, 68-87.

Chomczyński, P. (2013). Sposoby radzenia sobie z negatywnymi emocjami wśród wychowanków zakładów poprawczych w Polsce [The Ways of Dealing with Negative Emotions Among Inmates from Polish Reformatories]. Studia Edukacyjne, 26/2013, 185-204.

Chomczyński, P. (2013). Problem bezpieczeństwa personelu zakładów poprawczych dla nieletnich w kontaktach z wychowankami. Socjologiczna analiza czynników wewnętrznych [Safety of the Staff of Youth Detention Centers in Their Relations with Inmates: Sociological Analysis of Internal Factors]. Profilaktyka Społeczna i Resocjalizacja, 23/2013, 91-117.

Chomczyński, P. (2015). Problem etykietowania i stygmatyzacji wśród wychowanków zakładów poprawczych i schronisk dla nieletnich. Socjologiczna analiza zjawiska [The Problem of Labeling and Stigmatization Among Reformatories and Shelters' Inmates. Sociological Analysis of Phenomenon]. Studia Socjologiczne, 4(219), 205-236.

Collins, H. (2010). Tacit and Explicit Knowledge. Chicago: The University of Chicago Press Books.

Denzin, N. K. (1978). The Research Act: A Theoretical Introduction to Sociological Methods. New York: McGraw-Hill.

Hochschild, A. (2012). The Managed Heart Commercialization of Human Feeling, Updated with a New Preface. California: University of California Press.

Lave, J., \& Wenger, E. (1991). Situated Learning: Legitimate Peripheral Participation. Cambridge: Cambridge University Press.

Fujimura, J. H. (1997). The Molecular Biological Bandwagon in Cancer Research. In: L. A. Strauss (Ed.), Grounded Theory in Practice (pp. 261-283). Thousand Oaks, London-New Delhi: Sage Publications.

Glaser, B., \& Strauss, A. L. (2009). Odkrywanie teorii ugruntowanej [The Discovery of Grounded Theory. Strategies for Qualitative Research]. Translated by M. Gorzko. Kraków: Zakład Wydawniczy „Nomos”. 
Gabo, G. (2008). Doing Ethnography. Los Angeles-London-New Delhi-Singapore: Sage.

Golczyńska-Grondas, A. (2019). Wywiady biograficzne z osobami ze środowisk wykluczenia społecznego-refleksja and wybranymi problemami metodologicznymi i etycznymi [Biographical Interviews with Narrators Endangered by Social Exclusion - Some Thoughts on Ethical and Methodological Issues]. Przegląd Socjologii Jakościowej, XV/2, 178-201, doi: 10.18778/1733-8069.15.2.10.

Hałas, E. (1987). Społeczny kontekst znaczeń w teorii symbolicznego interakcjonizmu [Social Context of Meanings in the Theory of Symbolic Interactionism]. Lublin: Redakcja Wydawnictw KUL.

Hammerslay, M., \& Atkinson, P. (2007). Ethnography Principles in Practice, Third Edition. New York and London: Routledge Taylor \& Francis Group.

Jaworska, A. (2012). Kompetencje osobowościowe i zawodowe wychowawców resocjalizacyjnych [Personal and Professional Competences of Social Rehabilitation Educators]. In: A. Jaworska (Ed.), Leksykon resocjalizacji [Rehabilitation Lexicon], (pp. 92-97). Kraków: Impuls.

Kacperzyk, A. (2012). Świat społeczny [Social Words]. In: K.T. Konecki, \& P. Chomczyński (Eds.), Słownik socjologii jakościowej [Dictionary of Qualitative Sociology], (pp. 275-277). Warszawa: Wydawnictwo Difin.

Kacperczyk, A. (2016). Społeczne światy. Teoria - empiria, metody badań na przyktadzie świata wspinaczki [Social Worlds. Theory - Empiricism, Research Methods on the Example of the Climbing World]. Łódź: Wydawnictwo Uniwersytetu Łódzkiego.

Kleinknecht, S. (2007). An Interview with Robert Prus: His Career, Contributions, and Legacy as an Interactionist Ethnographer and Social Theorist. Qualitative Sociology Review, $3 / 2,221-288$.

Konopczyński, M. (2016). Osobowe przesłanki skutecznej resocjalizacji [Personal Premises for Effective Social Rehabilitation]. Resocjalizacja Polska, 11/2016, 5-8, doi: 10.22432/pjsr.2016.11.01.

Konopczyński, M. (2015). Pedagogika resocjalizacyjna - w stronę działań kreujących [Rehabilitation - Towards Creative Activities]. Kraków: Impuls.

Konecki, K. (2005). Teoria ugruntowana, a kontekst odkrycia. Naturalna historia pewnego badania [Grounded Theory and Context of Discovery. The Natural History of Some Study]. In: E. Hałas, \& K. Konecki (Eds.), Konstruowanie jaźni i społeczeństwa. Europejskie warianty interakcjonizmu symbolicznego [Constructing Self and Society. European Variants of Symbolic Interactionism], (pp.46-65). Warszawa: Wydawnictwo Scholar.

Konecki, K. (2000). Studia z metodologii badań jakościowych. Teoria ugruntowana [Studies in Qualitative Research Methodology. Grounded Theory]. Warszawa: PWN. 
Konecki, K. (2007). Nowi pracownicy a kultura organizacyjna przedsiębiorstwa. Studium folkloru fabrycznego [New Employess and Organization Culture Study in Factory Folklore]. Przegląd Socjologii Jakościowej, Monografie, 3/1.

Lewin, K. (1945). Action Research and Minority Problems. Journal of Social Issues, 2/4, $34-46$.

Lofland, J., Snow, D.A., Anderson, L., \& Lofland, L.H. (2009). Analyzing Social Settings: A Guide to Qualitative Observation and Analysis. Cheriton House, North Way, Andover, Hampshire: Cengage.

Manning, P. K. (1971). Talking and Becoming: A View of Organizational Socialization. In: J. D. Douglas (Ed.), Understanding Everyday Life (pp. 239-256). London: Routledge \& Kegan Paul.

Marciniak, Ł. (2008). Stawanie się nauczycielem akademickim: analiza interkacjonistyczno-symboliczna [Becoming an Academic Teacher: Symbolic Interactionist Analysis]. Przegląd Socjologii Jakościowej, 4/2, 1-131.

Mucha, J. (2003). Herbert Blumer jako badacz „stosunków rasowych” [Herbert Blumer as a Researcher of „Racial Relations]. Studia Socjologiczne, 3, 25-68.

Marzec, W. (2011), Granice (teorii) społecznych światów [Limits (Theories) of Social Worlds]. Przegląd Socjologii Jakościowej, 7/1, 3-21.

Nęcka, E., Orzechowski, J., \& Szymura, B. (Eds.) (2008). Psychologia poznawcza [Cognitive Psychology]. Warszawa: PWN.

Niedbalski, J. (2016). Dylematy etyczne i problemy metodo-logiczne warsztatu badacza na przykładzie badań prowadzonych w środowisku osób z niepełnosprawnością intelektualną oraz niepełnosprawnością fizyczną [Ethical Dilemmas and Methodological Problems of a Researcher's Workshops- Deliberations Based in the Example of Research Performed in the Environment of Individuals with Intellectual and Physical Disability]. Studia Humanistyczne AGH, 15/4, 37-53, doi: 10.7494/human.2016.15.4.35.

Nonaka, I., \& Takeuchi, H. (2000). Kreowanie wiedzy w organizacji. Jak spółki japońskie dynamizuja procesy innowacyjne [The Knowledge-Creating Company: How Japanese Companies Create the Dynamics of Innovation]. Warszawa: Poltext.

Orr, J. (1996). Talking about Machines: An Etnography of a Modern Job. Cornell: University Press.

Patton, M. (1997). Obserwacja - metoda badań terenowych [Observation - Field Research Method]. In: L. Korporowicz (Ed.), Ewaluacja w edukacji [Evaluation in Education], (pp.163-200). Warszawa: Wydawnictwo Oficyna Naukowa.

Polanyi, M. (1958). Personal Knowledge. London: Routledge \& Kegan Paul. 


\section{METODY ZBIERANIA I ANALIZY DANYCH W BADANIACH EDUKACYJNYCH}

Pytka, L. (1983). Pedagogika resocjalizacyjna. Wybrane zagadnienia teoretyczne, diagnostyczne i metodyczne [Pedagogy Rehabilitation. Selected Theoretical, Diagnostic And Methodological Issues]. Warszawa: Wydawnictwo Akademii Pedagogiki Specjalnej.

Ropski, J. (2010). Kompetencje interpersonalne w resocjalizacji [Interpersonal Competence In Rehabilitation]. In: B. Urban (Ed.), Aktualne osiagnięcia w naukach społecznych a teoria i praktyka resocjalizacyjna [Current Achievements in Social Sciences, and Social Rehabilitation Theory and Practice], (pp. 290-315). Kraków: Wydawnictwo Górnośląskiej Szkoły Wyższej, Impuls.

Ryle, G. (2009). The Concept of Mind. New York: Routledge Taylor \& Francis Group.

Shibutani, T. (1962). Reference Groups and Social Control. In: A. Rose (Ed.), Human Behavior and Social Processes (pp. 128-145). Boston: Houghton Mifflin.

Skuza, A. (2012). Klimat społeczny polskiego zakładu poprawczego (pedagogiczna analiza czynników kreujących) [The Social Climate of the Polish Correctional Institution (Pedagogical Analysis of the Creation Factors)]. Resocjalizacja Polska, 3, 361-382.

Słowińska, K. (2010). Społeczny świat hodowców gołębi pocztowych [The Social World of Pigeon Breeders]. In: Przegląd Socjologii Jakościowej, monografie, VI/3, Łódź.

Sternberg, R. J., \& Hedlund, J. (2002). Practical Intelligence and Work Psychology. Human Performance, 15(1/2), 143-160, doi: 10.1207/S15327043HUP1501\&02_09.

Strauss, A. L., \& Corbin, J. (1990). Basics of Qualitative Research. London: Sage.

Strauss, A. L. (1993). Cintinual Permutations of Action. New York: Aldine De Gruyter.

Strauss, A. L. (1978). Social Worlds Perspective. In: N. K. Denzin (Ed.), Studies in Symbolic Interaction (pp. 98-118). Greenwich: JAI Press.

Strauss, A. L. (2013). Zwierciadła i maski. W poszukiwaniu tożsamości [Mirrors and Masks: The Search for Identity]. Translated by A. Hałas. Kraków: Nomos.

Sobczak, S. (2007). KLIMAT społeczny instytucji resocjalizujących [Social CLIMATE of Social Rehabilitation Institutions]. Pedagogika Społeczna, 3, 133-152.

Szczepanik, R. (2015). Partnerki życiowe recydywistów i ich rola w powstrzymywaniu aktywności przestępczej [Life Partners of Reoffenders and Their Role in the Containment of Criminal Activity]. Profilaktyka Społeczna i Resocjalizacja, 26/2015, 35-57.

Szczepanik, R., \& Śliwerski, A. (2017). Obietnice bez pokrycia. Etyczne i prawne granice (nie)ujawniania informacji o przestępstwie w badaniach naukowych i psychoterapii [Empty Promises. Ethical and Legal Boundaries of (not) Disclosing Information about Crime in Scientific Research and Psychotherapy]. Przeglad Badań Edukacyjnych, 1/24, 151-177. doi: 10.12775/PBE.2017.009. 
Szczepanik, R. (2020). Rodzice osób pijących alkohol problemowo. O ambiwalencji pomocy [Parents of Problem Drinkers. About Help Ambivalence]. Łódź: Uniwersytet Łódzki.

Ślęzak, I. (2007). Stawanie się poetą: analiza interakcjonistyczno-symboliczna [Becoming a Poet: Symbolic Interactionist Analysis]. Przegląd Socjologii Jakościowej, 5/1, 3-167.

Ślęzak, I. (2016). Praca kobiet świadczacych ustugi seksualne w agencjach towarzyskich [The Work Of Women Providing Sexual Services In Escort Agencies]. Łódź: Wydawnictwo Uniwersytetu Łódzkiego.

Ślęzak, I. (2018). Praca nad zaufaniem. Etyczne, praktyczne i metodologiczne wyzwania w relacjach badacz-badani na przykładzie etnografii agencji towarzyskich [Trust Work. Ethical, Practical, and Methodological Challenges in Relations Between Researchers and Their Subjects, Based on An Ethnography of Escort Agencies]. Przeglad Socjologii Jakościowej, XIV/1, 138-162, doi: 10.18778/1733-8069.14.1.0.

Wilson, T. P. (1970). Conceptions of Interaction and Forms of Sociological Explanation. American Sociological Review, 35 (4), 697-710.

Wilson, T. P. (1971). Normative and Interpretative Paradigms in Sociology. In: J. D. Douglas (Ed.), Understanding Everyday Life: Toward the Reconstruction of Sociological Knowledge (pp.57-79). London: Routledge \& Kegan Paul.

Wyka, A. (1993). Badacz społeczny wobec doświadczenia [Social Researcher and Experience]. Warszawa: Wydawnictwo IFiS PAN.

Zalewski, G. (2004). Klimat społeczny instytucji resocjalizacyjnych a poziom psychotyzmu $u$ wychowanków [The Social Climate of Social Rehabilitation Institutions and the Level of Psychoticism in Juveniles]. Białystok: Wydawnictwo Akademii Medycznej.

Zięba-Kołodziej, B. (2010). Jakościowe badanie instytucji w pedagogice społecznej [Qualitative Study of Institutions in Social Pedagogy]. In: T. Frąckowiak, K. Marzec-Holka, \& A. Radziewicz-Winnicki (Eds.), Próby i szkice humanistyczne. Funkcje pedagogiki społecznej czasu teraźniejszego (mitu, wolności i młodej demokracji) [Humanities Trials and Sketches. Present-day Social Pedagogy Functions (Myth, Freedom and Young Democracy)], (pp. 353-354). Poznań: Wydawnictwo Naukowe Polskiego Towarzystwa Pedagogicznego.

Zmyślony, I. (2012). Kategoria wiedzy niejawnej (tacit knowledge): typowe sposoby rozumienia [Classified Knowledge Category (Tacit Knowledge): Typical Ways of Understanding.]. Filozofia Nauki, 20/3, 65-82. 